\title{
UNIVERSITY OF MICHIGAN RADIOCARBON DATES IV
}

\author{
H. R. CRANE and JAMES B. GRIFFIN \\ University of Michigan, Ann Arbor, Michigan
}

The following is a list of radiocarbon dates obtained since the time of the preparation of Michigan list III.* The description of the essential features of our method of measurement as given in the introduction to list III applies to this list. The modern standards used were obtained from hardwood logs, and were of various ages from 75 to 150 years by ring count. These standards were sufficiently old so that no correction for the recent dilution of the atmospheric $\mathrm{C}^{14}$ is believed to be necessary in the dates reported here. The ages of carbonate sample are also calculated from modern wood as a reference standard, without any correction for isotope fractionation.

We are pleased to acknowledge the help of Miss Patricia Dahlstrom for the chemical preparation of the samples, and that of Mr. James J. Taylor for assistance in the preparation of the descriptions of the samples. We are indebted to the Michigan Memorial-Phoenix Project for the major part of the financial support of the laboratory.

\section{SAMPLE DESCRIPTIONS}

\section{I, GEOLOGICAL SAMPLES}

M-219. George Reserve Lake, Michigan $\quad \mathbf{3 0 0 0} \pm \mathbf{5 0 0}$

Lake bottom muck from the George Reserve Lake $\left(42^{\circ} 27^{\prime} 30^{\prime \prime} \mathrm{N} \mathrm{Lat}, 84^{\circ}\right.$ $00^{\prime} 30^{\prime \prime}$ W Long), Livingston County, Michigan. The sample was taken from a depth of $15 \mathrm{ft}$ in the muck. Coll. 1951 and subm. by S. A. Cain, University of Michigan, Ann Arbor. Comment: other samples from different depths in this lake have been dated: (M-220, $4550 \pm 500$ at $20 \mathrm{ft}$, Michigan III; M-221, $5970 \pm 900$ at $25 \mathrm{ft}$, Michigan III; M-222, $8570 \pm 400$ at 30 to $31 \mathrm{ft}$, Michigan I; M-223, 11,450 \pm 600 at 35 to $36 \mathrm{ft}$, Michigan I; M-224, 11,450 \pm 600 at 40.25 to $41.25 \mathrm{ft}$, Michigan I).

\section{M-347. Russell Farm, Michigan}

$5950 \pm 300$

Mastodon tusk fragments from the "Russell Mastodon" found at the Frank Russell Farm $\left(43^{\circ} 00^{\prime} \mathrm{N}\right.$ Lat, $83^{\circ} 15^{\prime} \mathrm{W}$ Long), Lapeer County, Michigan. The tusk was found in the bulldozing of "spoil" dirt which had been taken out previously. The mastodon was buried under $18 \mathrm{in.} \mathrm{of} \mathrm{muck} \mathrm{in} \mathrm{marl} 2 \mathrm{ft}$ thick. The animal was considered to be a young adult male with short tusks. Coll. 1953 by Frank Russell; sulm. by C. W. Hibbard, University of Michigan, Ann Arbor. Data subm. by C. M. Barber.

\section{M-639. Coville Farm, Michigan}

$13,200 \pm 600$

Bone from woodland muskox taken from a marl pit on the Coville Farm $\left(42^{\circ} 12^{\prime} \mathrm{N}\right.$ Lat, $85^{\circ} 25^{\prime} \mathrm{W}$ Long), Kalamazoo County, Michigan. The sample was removed from the marl pit by shovel from 4 to $6 \mathrm{ft}$ below the surface. The

* References to published date lists, given in this form in the text, are given in full in the References. 
marl was 6 to $8 \mathrm{ft}$ deep, overlain by $1 \mathrm{ft}$ of muck. Coll. 1956 by Frank Hinds; subm. by C. W. Hibbard, University of Michigan, Ann Arbor.

\section{Michillinda Bog series, Michigan}

Wood samples from a buried peat bog exposed at Michillinda, Michigan on the east shore of Lake Michigan ( $43^{\circ} 21^{\prime} 24^{\prime \prime} \mathrm{N}$ Lat, $86^{\circ} 25^{\prime} \mathrm{W}$ Long). The bog is underlain by lake silts and glacial till and is covered by bedded sands and gravels. The peat deposition occurred during a low-water stage in the Lake Michigan Basin, probably the Chippewa level. Maximum thickness of the peat was 50 in. Pollen samples were collected in the 50-in. section; the wood was collected from various levels throughout the peat. Coll. 1955 by J. H. Zumberge and G. I. Quimby; subm. by Zumberge, University of Michigan, Ann Arbor. Zumberge and Potzger $(1955,1956)$ have published on the geological chronology of the Lake Michigan Basin.

\section{M-468. Michillinda Bog, stratigraphically lowest of samples}

White pine from base of peat layer in vicinity of 50 -in. pollen section. It is from just above layer of contact between peat and underlying sands and gravels and should date early period of peat formation.

\section{M-473. Michillinda Bog}

$4800 \pm 400$

White pine from near hase of peat bed but probably stratigraphically above M-468 since there was a lesser thickness of peat above this sample. Is at furthest distance from pollen section.

M-470. Michillinda Bog

$4890 \pm 300$

White oak from level 12 in. above M-468 in vicinity of pollen section.

M-471. Michillinda Bog

$4850 \pm 300$

Oak from same stratigraphic level as M-470 but from a section of the peat only $31 \mathrm{in}$. thick. Sample was from a small log whose center was above the base of the peat.

M-469. Michillinda Bog

$4750 \pm 300$

American elm from a log from the top of the peat in an area where it was 36 in. thick.

\section{M-472. Michillinda Bog}

$4100 \pm 250$

White pine. Sample was branch of a tree that lay 6 to 8 in. from the top of a 29 -in.thick section of the peat, about $5 \mathrm{ft}$, laterally, from the pollen section. Represents minimum date on the low-water stage in the Lake Michigan Basin.

\section{M-174. Michillinda Bog}

$$
5420 \pm 400
$$

White pine from within the body of peat but exact position not recorded.

\section{M-490. Sheridan, New York}

$9200 \pm 500$

Rib of young mastodon from Dahlman farm near Sheridan (ca. $42^{\circ} 30^{\prime}$ N Lat, $79^{\circ} 12^{\prime}$ W Long), Chautauqua County, New York. This find was reported by Hartnagel and Bishop (1921). The lower Warren beach at this spot has an elevation of $755 \mathrm{ft}$ and is about $300 \mathrm{ft}$ wide. The skeleton was found in 
muck land to south or landward side of the beach. The section showed $2 \mathrm{ft}$ of muck, $3 \mathrm{ft}$ of "quicksand" under which was a hard bed of sand. The tusks were driven into the sand a number of feet. Coll. 1955 by E. R. Burmaster; subm. by I. Reimann, University of Michigan, Ann Arbor.

\section{M-851. St. Vincent Island, West Indies}

$\mathbf{3 8 9 0} \pm \mathbf{3 0 0}$

Wood from $\log$ (species unknown) collected from a volcanic mudflow deposit on bank of Rabaka River about $3500 \mathrm{ft}$ from the east coast $\left(13^{\circ} 17^{\prime} 45^{\prime \prime}\right.$ $\mathrm{N}$ Lat, $61^{\circ} 07^{\prime} 50^{\prime \prime} \mathrm{W}$ Long), St. Vincent Island, Windward Islands, Lesser Antilles, West Indies. The volcanic mudflow deposit from which the sample was taken appears to be a basal portion of the prominent uppermost glowingavalanche from Mt. Soufriere exposed on the banks of the Rabaka River Valley. Coll. 1957 and subm. by R. L. Hay, University of California, Berkeley. Comment: the glowing-avalanche deposit predates the oldest known artifacts which occur in soil developed on the upper surface of the deposit. The deposit from which the dated sample was taken is on the younger deposits forming a broad alluvial fan on the east coast of St. Vincent.

\section{M-638. Lansing, Michigan}

$7460 \pm 400$

Wood sample (Larix laricina) from peat bog 1 to $10 \mathrm{ft}$ thick under $15 \mathrm{ft}$ of glacial moraine $20 \mathrm{ft}$ above river level at Lansing sewage disposal plant, Lansing ( $42^{\circ} 40^{\prime} \mathrm{N}$ Lat, 84 $34^{\prime} 40^{\prime \prime} \mathrm{W}$ Long), Michigan. Coll. 1949 by H. M. Martin, S. G. Bergquist, and L. Wood; subm. by H. M. Martin, Michigan Department of Conservation. Comment: sample was found when peat bog was exposed by an excavation made in the Grand Ledge Moraine in Lansing. When the sample was collected there was no evidence to contradict the assumption that the bog had been covered by an ice advance. Careful investigation following dating, however, disclosed that turf had been removed from a portion of Grand Ledge Moraine and then the morainic material had been bulldozed into the bog, burying the peat. The significance of the date, therefore, is limited to the establishment of the temporal existence of the bog. Another sample, possibly from the same wood or from different wood, was dated by the U.S.G.S. (sample no. W-556, Meyer Rubin, personal communication) at $9040 \pm 300$.

\section{M-723. Wolstenholme Fiord, Greenland $\quad 9880 \pm 500$}

Seaweed from the north side of Wolstenholme Fiord, near the terminus of Moltke Glacier and opposite the 1953 position of the end of Sermerssuag Glacier $\left(76^{\circ} 38^{\prime} 45^{\prime \prime} \mathrm{N}\right.$ Lat, $67^{\circ} 59^{\prime} 30^{\prime \prime} \mathrm{W}$ Long), Greenland. The specimen was collected from a 1 -ft-thick carbonaceous silty sand zone about midway in a $30-\mathrm{ft}$ bluff of sandy-gravel beach sediments. The middle third of the bluff sediments contains a marine pelecypod fauna. The top of this fossiliferous zone is about $35 \mathrm{ft}$ above the present average water level in the fiord. Coll. 1955 by C. D. Holmes; subm. by J. H. Zumberge, University of Michigan, Ann Arbor. Comment: Holmes has reported (personal communication to Zumberge) that pelecypod shells from both above and below the seaweed zone have yielded radiocarbon dates of about 9000 B.P., tending to confirm the date from this seaweed sample.

M-722. East Wyeth Group, Site \#4, Washington $\quad 670 \pm 300$ Stump of Douglas fir from submerged forest at East $W_{\text {yeth }}$ Group, Site 


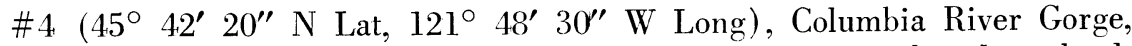
Washington. The stump was placed in soil. Submergence is attributed to a landslide blocking the gorge. This slide is estimated to have occurred $396 \mathrm{yr}$ ago or earlier on the basis of untilted trees growing on the landslide area itself. The stump had over 200 annual rings outside its rotten center and is estimated to have been approximately $260 \mathrm{yr}$ old at the time of submergence. Coll. 1936 by D. B. Lawrence and deposited with the Pacific Northwest Forest and Range Experiment Station, U. S. Forest Service. Subm. by L. Isaac for that organization through S. H. Spurr, University of Michigan, Ann Arbor. Lawrence has published a discussion of the submerged forest (1936). Comment: the date provided by the sample fits closely the expected total age of the wood of $656 \mathrm{yr}$.

M-761. Bingen, Washington $\quad \mathbf{7 0 0} \pm \mathbf{2 0 0}$

Garry oak stump submerged in the Columbia River Gorge near Bingen ( $45^{\circ} 40^{\prime} \mathrm{N}$ Lat, $121^{\circ} 26^{\prime} 30^{\prime \prime} \mathrm{W}$ Long), Washington. This stump, like M-722 above, is one of the trees drowned by the lake formed behind the Cascade Landslide at the Columbia River Gorge. Coll. 1936 and subm. by D. B. Lawrence, University of Minnesota, Minneapolis. Comment: the sample was carefully prepared by Lawrence to avoid contamination. All faces previously in contact with air were removed with clean tools and the sample was then wrapped immediately in several layers of aluminum foil and enclosed in two plastic bags.

\section{ARCHAEOLOGICAL SAMPLES}

\section{A. Middle Western United States}

\section{M-558. Wilson Mound, Illinois}

$1950 \pm 200$

Antler from Wilson Mound ( $37^{\circ} 59^{\prime} \mathrm{N}$ Lat, $88^{\circ} 2^{\prime} \mathrm{W}$ Long) near Wabash River, Emma Township, White County, Illinois. The sample was obtained as an artifact, part of a stone-working kit, placed with a corpse in a typical central log tomb chamber in the mound. It was in an exhibit case for five years prior to dating. Coll. 1950 by G. K. Neumann; subm. by Thorne Deuel, Illinois State Museum, Springfield. Comment: the Wilson Mound is a Southern Illinois Hopewell site. It has heen described by Neumann and Fowler (1952). Three other dates have been published for the log burial chamber from which the antler sample was collected: (C-684, $2086 \pm 160$, reported in Deuel $(1952$, p. 91) ; C-684, average $723 \pm 180$, Chicago III, p. 675; and M-559, $2000 \pm 200$, Michigan III, p. 1119). These first two dates are both from the same sample (C-684). The discrepancy between them is discussed by Griffin $(1958$, p. 12) . The agreement betwen the dates provided by M-558, M-559, and the first dating of C-684, indicates that the second date derived from this specimen (723 $\pm 180)$ is in error.

\section{M-574. Long Slough, Illinois}

$1350 \pm 500$

Contemporary mussel shell specimen taken from Long Slough, a marshy backwater area within $400 \mathrm{yd}$ of the Kuhne site-see below, M-578-580 (41 ${ }^{\circ}$ $9^{\prime} \mathrm{N}$ Lat, $89^{\circ} 18^{\prime} \mathrm{W}$ Long), in the Illinois River Valley. The specimen was gathered alive from Long Slough, the source of many of the mussels utilized by the inhabitants of the Kuhne Site. Coll. 1956 and subm. by Stuart Struever, 
La Salle-Peru, Illinois. Comment: the date gives added evidence of the error apparently inherent in the use of some shell samples. This has been discussed (Michigan I, p. 664). It should be noted that the apparent age of these modern shells is calculated on the assumption that shell and wood do not differ in $\mathrm{C}^{14}$ content.

\section{Kuhne Site series, Illinois}

Charcoal from Kuhne Site $\left(41^{\circ} 9^{\prime} \mathrm{N}\right.$ Lat, $89^{\circ} 18^{\prime} \mathrm{W}$ Long), Putnam County, Illinois. Samples were collected during controlled excavation of the site done in 5 -ft squares at depths of $50 \mathrm{in.}$ (datum for the site) and less. Coll. 1956 and subm. by Stuart Struever, La Salle-Peru, Illinois.

M-578. Kuhne Site

$1670 \pm 200$

From square K-939, 17 in. from north wall, 6 in. from west wall, 50 in. below ground surface. Sample was part of a charcoal ash lens probably representing a fire of short duration.

M-579. Kuhne Site

$2210 \pm 250$

From square K-1085, 24 in. from north wall, 24 in. from east wall, 32 in. below ground surface. Sample was part of small pocket of charcoal within the general refuse area of this village site.

M-580. Kuhne Site

$1790 \pm 300$

From square K-1126, 18 in. from north wall, 16 in. from west wall, 39 in. below ground surface. Comment: the Kuhne Site is primarily Hopewellian, seemingly occupied intermittently from late pre-Hopewell times to post-Hopewellian Late Woodland. The significance of these dates will be discussed by Struever in his report on the site. The dates fit closely with Hopewell dates given in Michigan I, II, III.

\section{M-726. Raaf Shell Mound, Indian}

$1800 \pm 200$

Contemporary mussel shell (id. by G. A. Black) from beach of Ohio River immediately adjacent to Raaf Shell Mound $\left(37^{\circ} 58^{\prime} 9^{\prime \prime} \mathrm{N}\right.$ Lat, $86^{\circ} 52^{\prime} 23^{\prime \prime} \mathrm{W}$ Long), Huff Township, Spencer County, Indiana. The sample was collected as a living animal to be dated as a check on the dates for this Archaic Shell Mound hased on shell material. Coll. 1956 by Mr. and Mrs. G. F. Martin; subm. by G. A. Black, R. R. 2, Newburgh, Indiana. Comment: the date is clearly older than might have been expected. In this it is similar to M-574 (see above) and indicates the tendency of some shell to yield dates which are too ancient (Michigan I, p. 664). However, the date of this contemporary specimen-- $1800 \mathrm{yr}$ - when subtracted from previous dates for the Raaf Shell Mound based on shell material (Michigan II, p. 1100) which average ca. $6000 \mathrm{yr}$, gives a figure well in line with dates for late Archaic shell mounds based on other than shell material, as given in Libby (1955). It should be noted that the apparent age of these modern shells is calculated on the assumption that shell and wood do not differ in $\mathrm{C}^{14}$ content.

\section{Carcajou Point series, Wisconsin}

Charcoal associated with artifacts from Carcajou Point $\left(42^{\circ} 53^{\prime} 21^{\prime \prime} \mathrm{N}\right.$ Lat, $88^{\circ} 57^{\prime} 30^{\prime \prime} \mathrm{W}$ Long) and Carcajou Point Village $\left(42^{\circ} 53^{\prime} 22^{\prime \prime} \mathrm{N}\right.$ Lat, 
$88^{\circ} 57^{\prime} 30^{\prime \prime} \mathrm{W}$ Long), Lake Koshkonong, Jefferson County, Wisconsin. The artifacts are typologically primarily Upper Mississippi with some evidence of continuity from Middle Mississippi traits. Archaeological problems of the area and previous radiocarbon dates are discussed by Hall (1958, and ms.). Coll. 1957 and subm. by R. L. Hall, Lincoln-Tallman Historical Museum, Janesville, Wisconsin.

M-786. Carcajou Point Village

$960 \pm 250$

Charcoal recovered from the general fill of a refuse pit (feature 41) within the area enclosed by the outline of a house of wall trench construction (feature 61). Pottery associated with this sample is regarded typologically as representing an early phase of an occupation Upper Mississippi in total character, but marked by attenuated Middle Mississippi traits in ceramics and house construction.

M-785. Carcajou Point Village

$930 \pm 250$

Charcoal from the fill of a post mold $1 \mathrm{ft}$ in diameter (feature 57) centered exactly within the outline of the house (see above-feature 61). The date determined for this sample differs from that for M-786 by only $30 \mathrm{yr}$. As both samples are from features (4l and 57) within the same house outlines (feature 61 ), all three features would appear to be essentially contemporaneous.

\section{M-747. Carcajou Point}

$430 \pm 250$

Charcoal from level 3 of a refuse-filled pit (feature 17) in an occupational area, unassociated with any structural features. Pottery associated with this sample is regarded as typologically later than that associated with M-786 from another refuse-filled pit (feature 4l). The radiocarbon dates are thus consistent with the archaeological evidence and my be regarded as restricting in time the late phase of an Upper Mississippi occupation at this site.

\section{M-784. Raddatz Rockshelter, Wisconsin}

$1380 \pm 200$

Charred wood from the Raddatz Rockshelter $\left(43^{\circ} 21^{\prime} \mathrm{N}\right.$ Lat, $89^{\circ} 56^{\prime} \mathrm{W}$ Long), Sauk County, Wisconsin. The sample was taken from a firebed in level 6 (20 to $24 \mathrm{in}$. below surface). Two large side-notched projectile points were found in this firebed. These and other associated materials from elsewhere in the shelter at the same depth are typologically Middle Archaic. Coll. 1957 and subm. by W. L. Wittry who has a final report on the site scheduled for publication in the Wisconsin Archeologist during 1959. Comment: the artifacts associated with this sample, being of Middle Archaic type, suggest a date much earlier than the $1380 \pm 200$ given. See Michigan I, II, III for other radiocarbon dates for archaic materials.

\section{M-835. Coufal Site, Nebraska}

$820 \pm 200$

Charcoal from a center post of House \#20, a rectangular structure with four center posts, Coufal Site $\left(41^{\circ} 23^{\prime} \mathrm{N}\right.$ Lat, $98^{\circ} 44^{\prime} \mathrm{W}$ Long), David Creek Reservoir, Howard County, Nebraska. Coll. 1939 by A. T. Hill; subm. for Missouri Basin Chronology Program through R. L. Stevenson by M. F. Kivett, Nebraska Historical Society, Lincoln. Comment: the artifactual material recovered from this site indicates a blending of Nebraska culture and Upper 
Republican traits. The assemblage is referred to by Kivett as a "Hybrid Culture." The sample should date the transition between these two horizons.

\section{M-836. Crow Creek Site, South Dakota}

$900 \pm 200$

Charcoal from two house posts, Crow Creek Site $\left(43^{\circ} 59^{\prime} 50^{\prime \prime} \mathrm{N}\right.$ Lat, $99^{\circ}$ $19^{\prime} 54^{\prime \prime}$ W Long), Fort Randall Reservoir, Buffalo County, South Dakota. Coll. 1955 and subm. by M. F. Kivett, Nebraska Historical Society, Lincoln. Comment: the house post remains were taken from the floor of a long rectangular house. Two such houses were excavated at the site, both being of the Over Focus. The sample dates this component at this site. This Over Focus component is separated geographically and stratigraphically from a later prehistoric component at the same site.

\section{M-838. Thomas Riggs Site, South Dakota}

$730 \pm 200$

Charcoal from a burned house post, house \#2, Thomas Riggs Site $\left(44^{\circ}\right.$ $29^{\prime} 05^{\prime \prime}$ N Lat, $100^{\circ} 34^{\prime} 05^{\prime \prime}$ W Long), Oahe Reservoir, Hughes County, South Dakota. Coll. 1952 and subm. by W. R. Hurt, University of South Dakota, Vermillion, who has published a report on the site (Hurt, 1953). Comment: the sample is judged to provide a base date for the Thomas Riggs Focus and to date the long rectangular house component at the Riggs Site.

\section{M-453. Liverpool Mounds, Illinois}

$1470 \pm 200$

Wood from "Log-pen" burials, Mound F ${ }^{\circ} 7$, Liverpool Mounds $\left(40^{\circ} 23^{\prime}\right.$ $\mathrm{N}$ Lat, $90^{\circ} 0 \mathrm{I}^{\prime} 15^{\prime \prime} \mathrm{W}$ Long), Liverpool Township, Illinois. Mound $\mathrm{F}^{\circ} 77$ is one of four mounds built on an elevation of a bar of sand and gravel close to the banks of the Illinois River. The gravel, laid down by the receding ice, is overlain by 2.5 to $3 \mathrm{ft}$ of organically darkened sand. Mound $\mathrm{F}^{\circ} 77$ was built on this deposit. Coll. 1926 by Marion and Ernest Dickson; subm. by D. F. Dickson, Illinois Department of Conservation, who has described the archeology of the site (1956). Comment: the $\log$ tomb from which the sample was taken derives from a period of Hopewell culture occupation. Below the level of Hopewell occupation-in the "black sands"- other burial remains have been found deriving from a pre-Hopewell occupation. The sample provides a date for Hopewell at this site which is substantially later than the large number of radiocarbon dates for Hopewellian culture reviewed by Griffin (1958). The date is believed to be about 50 to $800 \mathrm{yr}$ too recent.

\section{M-642. Aztalan Site, Wisconsin}

$\mathbf{3 2 0} \pm \mathbf{2 0 0}$

Charcoal from the charnel house (crematorium) $2.3 \mathrm{ft}$ in depth in stage C (top level) of northwest pyramidal mound, Aztalan Site $\left(43^{\circ} 4^{\prime} \mathrm{N} \mathrm{Lat}, 88^{\circ}\right.$ $55^{\prime}$ W Long), Jefferson County, Wisconsin. The excavation of this feature is described in Rowe (1958). Coll. by C. W. Rowe in the summer of 1954; subm. by Robert Ritzenthaler, Milwaukee Public Museum, Wisconsin. Comment: this date is believed to be too late for the Aztalan occupation.

\section{Renner Site series, Missouri}

Charcoal associated with living debris from the Renner Site (ca. $39^{\circ} 10^{\prime}$ N Lat, $94^{\circ} 35^{\prime} \mathrm{W}$ Long), Platte County, Missouri. This is the type site of the Kansas City focus of the Hopewellian culture (Wedel, 1943). The excavations 
which produced the charcoal for these three dates are described in a later publication (Roedl and Howard, 1957).

M-571. Renner Site

$1850 \pm 200$

Charcoal from level 4, square 70 E 5 associated with village debris.

M-572. Renner Site

$1950+250$

Charcoal from pit 7, level 3, 12 to $18 \mathrm{in}$. associated with village debris.

\section{M-573. Renner Site}

$1520 \pm 200$

Charcoal from pit 7, level 4,18 to 24 in. associated with village debris. Comment: these three dates are regarded as of the correct age for this western Hopewell concentration, in contrast to the first date (M-454, $1270 \pm 250$, Michigan III), which is almost certainly too late (Griffin, 1958).

\section{M-585. O'Bryan Ridge (23 Mi 20), Missouri}

$1880 \pm 200$

Charred acorn meats (id. by V. H. Jones) from the Burkett or O'Bryan Ridge Site ( $36^{\circ} 52^{\prime} \mathrm{N}$ Lat, $89^{\circ} 12^{\prime} 30^{\prime \prime} \mathrm{W}$ Long), Mississippi County, Missouri. The sample was taken from excavation trench 4, level 5, 18 to $21 \mathrm{in}$. The pottery from this level is predominantly Mulberry Creek Cord-Marked, with minor proportions of Withers Fabric-Impressed and Baytown Plain. The site was occupied during Archaic and Woodland times. Coll. by E. G. Scully; subm. by J. B. Griffin. Comment: another date from this site has been recorded (M-438, $2140 \pm 250$, Michigan III) .

\section{M-309. Spiro Site, Oklahoma}

$480 \pm 200$

Conch shell fragments (Busycon?) from the surface of the destroyed Craig mound ( $35^{\circ} 14^{\prime} \mathrm{N}$ Lat, $94^{\circ} 40^{\prime} \mathrm{W}$ Long), Le Flore County, Oklahoma. Though these specimens were collected on the surface they are almost certainly from the large cache of marine shells from this mound (Hamilton, 1952). Coll. February 14, 1953 and subm. by L. H. Larson, 735 West Avenue, Cartersville, Georgia. Comment: earlier dates on Spiro well-preserved juniper by the carbonblock method resulted in an absurdly high figure (M-44, average $2286 \pm 200$, Michigan I), but with a gas counter a Spiro wood sample resulted in fairly close agreement with the present sample (M-54, $640 \pm 250$, Michigan I).

\section{M-446. Bedford Mound Group, Illinois $\quad 1550 \pm \mathbf{2 5 0}$}

Wood specimen from central $\log$ tomb of mound $\mathrm{Pk}^{\circ} 459\left(39^{\circ} 32^{\prime} \mathrm{N}\right.$ Lat, $90^{\circ} 35^{\prime} \mathrm{W}$ Long), near Bedford, Pike County, Illinois. This log tomb contained an incomplete child's skeleton and other skeletal material in one corner. In the tomb were three cut mica sheets, a fragment of a turtle carapace, a small copper awl, and a conch shell fragment with an engraved bird design. Coll. by Gregory Perino and Dan Morse; subm. by Morse, Peoria Municipal Tuberculosis Sanatorium, Peoria, Illinois. Comment: this date is somewhat younger than expected (Griffin, 1958, p. 14-15). A publication on the Bedford Mound Group is in preparation by Gregory Perino for the Gilcrease Foundation.

\section{M-549. Esther Berry Site, Illinois}

$810 \pm 250$

Charcoal from a Spoon River Focus village site, Esther Berry by name $\left(40^{\circ} 23^{\prime} 30^{\prime \prime} \mathrm{N}\right.$ Lat, $90^{\circ} 04^{\prime} 30^{\prime \prime} \mathrm{W}$ Long), Liverpool Township, Fulton County, Illinois. Coll. by Marion Dickson prior to 1956; subm. by J. B. Griffin. 


\section{Crable series, Illinois}

The Crable Site is a large Spoon River Focus, Middle Mississippi Phase village $\left(40^{\circ} 11^{\prime} 15^{\prime \prime} \mathrm{N}\right.$ Lat, $90^{\circ} 13^{\prime} \mathrm{W}$ Long $)$, Kerton Township, Fulton County, Illinois. A report on the site has been published by Smith (1951).

M-550. Crable Site

Charcoal from a post hole, probably part of a house structure, ca. $475 \mathrm{ft}$ SW of $F^{\circ} 898$ and $270 \mathrm{ft}$ WNW of Pit A (see site map in Smith, 1951). Coll. 1956 and subm. by J. B. Griffin and A. C. Spaulding.

M-553. Crable Site

$620 \pm 200$

Charcoal from Pit 1 at a depth of $2.5 \mathrm{ft}$. Coll. 1956 and subm. by Dan Morse, Peoria, Illinois.

M-554. Crable Site

$\mathbf{5 3 0} \pm \mathbf{2 0 0}$

Charcoal from Pit 1 at a depth of $3 \mathrm{ft}$. Coll. 1956 and subm. by Dan Morse, Peoria, Illinois. Comment: in the Central Illinois valley there is clear evidence of an early Mississippi stage derived from the Old Village level at Cahokia, and this occupation has not yet been dated. The Crable dates indicate that by A.D. 1300 the Spoon River Focus had assumed its distinctive form. The late expressions of the Spoon River Focus probably come close to A.D. 1700.

\section{Cahokia series, Madison County, Illinois}

The Ramey Site ( $38^{\circ} 39^{\prime} 30^{\prime \prime} \mathrm{N}$ Lat, $90^{\circ} 3^{\prime} 30^{\prime \prime} \mathrm{W}$ Long) is just east of Monks Mound in the heart of the Cahokia area, Illinois. Cahokia is an area of sites which range in time from the latter part of Late Woodland through several Mississippian stages.

M-635. Mound 34

$670 \pm 200$

Charred wood, both red oak group and hickory (id. by S. B. Preston), from "ceremonial fire," an area, $6 \mathrm{ft}$ in diameter, of a series of fires, at the junction of the ramp to the west side of the mound. Should postdate the construction of the ramp and the building of the mound. A number of artifacts were found in association; many show relationships to Spiro. Coll. 1956 by Gregory Perino; subm. by Perino and D. F. Morse, University of Michigan, Ann Arbor. Comment: another date from this mound has been published (M33 , average $800 \pm 200$, Michigan I) which came from Feature 4 at a depth of $4.25 \mathrm{ft}$ in the submound village debris. A publication on the Cahokia area is in preparation by Gregory Perino for the Gilcrease Foundation.

M-636. $150 \mathrm{yd}$ E of Monks Mound

$660 \pm 200$

Charcoal from lowest level of a refuse pit which should equate with Mound 34. in time. Coll. 1956 by Gregory Perino; subm. by J. B. Griffin.

M-670. 150 yd E of Monks Mound

$960 \pm 250$

Charcoal from small log lying on clay floor of burned house. Sherds from floor of house and in fill immediately above it indicate the Trappist complex. Coll. 1957 and subm: by D. F. Morse, University of Michigan, Ann Arbor. Comment: this date is a little early; see M-672. 
M-672. 150 yd E of Monks Mound

Charcoal from a basin in clay floor of burned house; same house dated by M-670. Coll. 1957 and subm. by D. F. Morse, University of Michigan, Ann Arbor. Comment: the radiocarbon dates from Cahokia do not yet reach back to the "earliest" Mississippi culture occupation. The Old Village culture type is well developed by A.D. 1100. Additional samples will he run in the near future on charcoal from the basal levels of the Kunneman mound on a "pure" Old Village complex excavated by Preston Holder.

\section{M-643. Osceola Site, Wisconsin}

$\mathbf{3 4 5 0} \pm \mathbf{2 5 0}$

Human bone from the Osceola Site $\left(42^{\circ} 39^{\prime} \mathrm{N}\right.$ Lat, $90^{\circ} 41^{\prime} 30^{\circ} \mathrm{W}$ Long), Grant County, Wisconsin. The burial layer from which the sample was collected was from 2.5 to $5 \mathrm{ft}$ below the ground surface. Between the burial layer and the topsoil was a layer containing isolated fragments of late Woodland pottery and broken chert points. Coll. 1945 and subm. by Robert Ritzenthaler. Milwaukee Public Museum, Milwaukee, Wisconsin, who has published a report on the site (1957). Comment: see below (M-644).

\section{M-644. Reigh Site, Wisconsin}

$3660 \pm 250$

Human bone from the Reigh Site $\left(44^{\circ} 03^{\prime} \mathrm{N}\right.$ Lat, $88^{\circ} 38^{\prime} \mathrm{W}$ Long), Winnebago County, Wisconsin. The burials from which the sample was obtained were in a gravel layer with no stratigraphy. The burials varied in depth from 1.5 to $5 \mathrm{ft}$, but the actual depth is unknown since the top surface level was removed by earth-moving machinery. Coll. 1956 by Neil Ostberg; subm. by Robert Ritzenthaler, Milwaukee Public Museum, Milwaukee, Wisconsin, who has published a report on this site (1957). Comment: The Osceola Site above (M-643) represents Old Copper culture. Ritzenthaler interprets the Reigh Site as a Glacial Kame culture, but the asociated artifacts show it to be a mixture of Old Copper and Glacial Kame. Samples from other Old Copper culture sites have been dated: Riverside Cemetery, Menominee County, Michigan (M-658, $3040 \pm 300$, Michigan III) ; Isle Royal copper mines, Keewenaw County, Michigan (M-320, 3000 \pm 350 , and M-371E, 3800 \pm 500 , Michigan I). These dates, in conjunction with those for the Osceola and Reigh sites, suggest that the earlier Old Copper samples from Oconto Cemetery, Wisconsin dated by the Chicago Laboratory (C-836, $5600 \pm 600$, and C-8.37 and C-839 combined, $7510 \pm 600$, Chicago V) are much too early.

\section{B. Northeastern United States and Canada}

\section{M-537. Lichliter Village Site, Ohio}

$1600 \pm 250$

Charred wood and charcoal from postholes and firepits in house sites, Lichliter Village Site $\left(39^{\circ} 46^{\prime} \mathrm{N}\right.$ Lat, $84^{\circ} 16^{\prime} \mathrm{W}$ Long), Montgomery County, Ohio. Coll. 1954-1956 and subm. by J. C. Allman, 1336 Cory Drive, Dayton 6 , Ohio, who has published a description of the site (1957). Comment: the artifactual material from this site represents a new culture for Ohio to which no name has as yet been assigned. It is generally accepted to be Late Woodland, between the end of Ohio Hopewell and the beginning of Fort Ancient. The date supplied by this sample agrees with this interpretation but may be somewhat early. 
Carbonized remains of two small logs (id. as a member of the white pine group, probably Pinus strobus), found in direct association with a partially cremated burial (burial \#4) near the eastern end of Serpent Mounds $\left(44^{\circ} 12^{\prime}\right.$ $24^{\prime \prime}$ N Lat, $78^{\circ} 05^{\prime} 14^{\prime \prime}$ W Long), Otonabee Township, Peterborough County, Ontario, Canada. This primary inclusive partial cremation was lying in a flexed position on the right side in fill $2.1 \mathrm{ft}$ below the mound surface. Coll. 1956 and subm. by R. B. Johnston, 7450 Holliday Drive E, Indianapolis, Indiana, who has published reports on the site (1958a, 1958b). Comment: the charcoal, which was found beside the vault of the skull, is most easily interpreted as the remains of $\log s$ used to cremate the buried individual. The date from the sample would therefore date the burial and supply a minimum date for the portions of the mound below the burial. The ceramic material from this site suggests a placement in Point Peninsula II.

\section{M-128. Killarney Bay, Ontario}

$2010 \pm 200$

Beaver fur from site KB1, Killarney Bay $\left(45^{\circ} 59^{\prime} \mathrm{N}\right.$ Lat, $81^{\circ} 30^{\prime} \mathrm{W}$ Long), Rutherford Township, Manitoulin District, Ontario. The sample was wrapped around four copper celts with flattened narrowed polls, a large copper four-sided awl or spindle, about 550 small copper beads, and 15 shell beads. These materials were with burial no. 8. The site apparently runs from Early Woodland into Hopewellian times. Coll. August 1952 and subm. by E. F. Greenman, University of Michigan, Ann Arbor.

M-640. Morrow Site, New York

$\mathbf{2 5 2 0} \pm \mathbf{2 5 0}$

Charcoal from a depth of $22 \mathrm{in.}$., Morrow Site $\left(42^{\circ} 47^{\prime} \mathrm{N}\right.$ Lat, $77^{\circ} 30^{\prime} \mathrm{W}$ Long), Ontario County, New York. The sample was associated with charred net fragments, net sinkers, red paint, and cremated bones. Coll. 1956 by H. L. Schoff and A. K. Guthe; subm. by Guthe, Rochester Museum of Arts and Sciences, Rochester, New York, who has published a description of the archaeology of the site (1958). Comment: the materials associated with the sample and other artifacts recovered at the site, including cache blades, bird stones, netsinkers, powdered hematite, a celt, copper beads, a pottery tubular-pipe section with expanded bit, gorgets of rectangular and diamond shape, and pottery of Vinette I type, indicate a Point Peninsula complex. Guthe considers the site a Point Peninsula II occupation. The date for this occupation provided by the sample agrees with other Point Peninsula and Early-Middle Woodland dates as summarized by Griffin (1958).

M-6.51. (Oakfield Site, New York

$120 \pm 150$

Charcoal from a refuse-filled pit, ()akfield Site $143^{\circ} 94^{\prime} 08^{\prime \prime} \mathrm{N}$ Lat, $78^{\circ}$ $17^{\prime} 13^{\prime \prime}$ W Long), Cenesee County, New York. The pit, which was unstratified, was at a depth of 18 in. below the ground surface. Coll. 1955 hy L. L. Pechuman; sulom. by M. E. White, Rochester Museum of Arts and Sciences, Rochester, New York. Comment: pottery was found in association with the sample in the refuse pit. This cultural material was representative of that found throughout the village site, which has been classified as Transitional Iroquois. The sample then dates this phase at this site. 
Charcoal from storage pit, Bates Site $\left(42^{\circ} 17^{\prime} 50^{\prime \prime}\right.$ N Lat, $75^{\circ} 47^{\prime} 42^{\prime \prime} \mathrm{W}$ Long), Creen Township, Chenango County, New York. The sample was obtained from the bottom layer of the roughly stratified refuse deposit in the storage pit which was bell-shaped ( $27 \mathrm{in}$. at top, $38 \mathrm{in}$. at bottom, $38 \mathrm{in}$. deep). Potsherds, an arrowpoint, and other artifacts were found in association with the charcoal. Coll. 1957 and subm. by W. A. Ritchie, New York State Museum, Albany. Comment: this site is of the Owasco culture. The date given by the sample for this Late Woodland complex agrees fairly well with previous dates for Early Owasco material from the Snell Site, Montgomery County (M-178, $1170 \pm 200$, Michigan II) and the White Site, Chenango County (M-176, $1050 \pm 250$, Michigan I).

\section{M-763. Getman Site, New York}

$\mathbf{5 6 0} \pm \mathbf{1 5 0}$

Charcoal from bottom of oval hearth 7 in. below plow line, Getman Site $\left(42^{\circ} 57^{\prime} 42^{\prime \prime} \mathrm{N}\right.$ Lat, $74^{\circ} 30^{\prime} 50^{\prime \prime}$ W Long), Palatine Township, Montgomery County, New York. The hearth from which the sample was obtained was one of the central fireplaces in a longhouse floor which was fully exposed. Coll. 1957 and subm. by W. A. Ritchie, New York State Museum, Albany. Comment: the sample dates Early Mohawk-Iroquois culture at this site.

\section{M-782. Woodchuck Hill, New York}

$1750 \pm 200$

Wood charcoal from Woodchuck Hill (or Scottsville site) $1 \mathrm{mi} \mathrm{SE}$ of Scottsville, Wheatland Township $\left(43^{\circ} 00^{\prime} 50^{\prime \prime}\right.$ N Lat, $77^{\circ} 43^{\prime} 53^{\prime \prime}$ W Long), Monroe County, New York. Sample came from a hearth or fireplace at bottom of a small pit with the exact provenience unknown. Coll. 1935 and subm. by W. A. Ritchie, New York State Museum, Albany. Comment: this date was regarded by Ritchie as much too recent and as inconsistent with other Lamoka culture dates. The same sample was run again with a result of $1270 \pm 200$. This sample is not apparently from a "pure" Lamoka site. There is some confusion in the literature on the age of the Lamoka complex. The following dates are known to Griffin: (C.191, 4930 \pm 260 ; C-288, average 4369 \pm 200 ; C. $367,5383 \pm 250$, Chicago I, p. 114, on carbon black); M-195, 4530 400 ; M-26, average $4445 \pm 400$, Michigan I on carbon black; and Y.459, $3870 \pm 80$, Yale IV), but four out of the first five runs are seldom used in statements on the age of Lamoka. Michigan has two additional samples from the type station of this so-called "Early" Archaic site.

\section{M-761. Wapanucket Site \# 6, Massachusetts $\quad 1250 \pm 300$}

Carbonized wood sticks and hark-from pit dug adjacent to Lodge Floor \#5. Wapanucket Site \#6 $\left(41^{\circ} 5 \mathrm{I}^{\prime} 8^{\prime \prime} \mathrm{N}\right.$ Lat, $70^{\circ} 54^{\prime} 6^{\prime \prime}$ W Long), north shore of Lake Assawompsett, Middleboro Township, Plymouth County, Massachusetts. The pit, $38 \mathrm{~cm}$ in diameter and $15 \mathrm{~cm}$ in depth, was dug in yellow sand and covered with the same material. The carbonized wood was found in from light to heavy deposits throughout the pit. Coll. 1957 by W. A. Ritchie; subm. by Maurice Robbins, 23 Steere Street, Attleboro, Massachusetts. Comment: the site was composed of seven lodge floors of a different plan from that found before in the area. The associated lithic material is typologically Ar- 
chaic. Since the site appears to be single component, it is assumed that the sample is associated with the lodge floors and lithic materials and dates them.

\section{Bull Brook Site series, Massachusetts}

Charcoal from the Bull Brook Site $\left(42^{\circ} 37^{\prime} 15^{\prime \prime} \mathrm{N}\right.$ Lat, $70^{\circ} 51^{\prime} \mathrm{W}$ Long), Ipswich, Massachusetts. The site is on kame terrace. The first level of soil above the terrace is composed of cross-bedded sand; above this is 18 to $30 \mathrm{in}$. of structureless sand. Between this and the ground surface is sandy loam. The charcoal occurred as crumbs scattered through reddened areas in the lower half of the structureless sand layer. Fluted points and associated artifacts occurred in these same areas, as well as some fragments of bone. No artifacts, charcoal, or bone were in portions of this layer of soil which were not reddened. None occurs either above or below this horizon. The charcoal is not from any single hearth. It appears to have been blown from fires and scattered over the site, settling in occupied areas. Since it occurs above, below, and among artifacts, it appears to equate with the laying down of the deposit rather than with any particular hearth. Excavations have indicated a considerable amount of disturbance of this soil zone as a result of trampling by the makers of the artifacts and later frost and wind action. Since, however, the charcoal and artifacts occur scattered equally and in association, they appear contemporaneous.

\section{M-807. Bull Brook Site}

Coll. 1957 by W. A. Eldridge; subm. by D. S. Byers, Peabody Foundation for Archaeology, Andover, Massachusetts.

M-810. Bull Brook Site

$8940 \pm 400$

Coll. 1957 and subm. by D. S. Byers.

M-808. Bull Brook Site

$8720 \pm 400$

Coll. 1955 by W. A. Eldridge; subm. by D. S. Byers.

M-809. Bull Brook Site

$6940 \pm 800$

Coll. 1957 and subm. by D. S. Byers. Comment: the first three samples (M-807. M-810, and M-808) do not differ significantly; they all fall within the combined standard deviations of the earliest and latest of the three dates. M-809 was a small sample and was not expected to be as reliable as the others. The dates provided by the first three agree with radiocarbon dates obtained from other sites containing fluted points of "Clovis" type. See Michigan I, and Libby (1955). Byers and Eldridge have reported on this site in several publications (Byers, 1954, 1955, 1956; Eldridge and Vaccaro, 1952).

\section{Soulheastern L nited Stales}

\section{M-164. Thursby Midden, Florida}

$650 \pm 200$

Fragment of large (arved wooden (southern pine) figurine of an owl from sile of 'Thurshy Midden (28 $58^{\prime} 30^{\prime \prime} \mathrm{N}$ Lat, $81^{\circ} 21^{\prime} 30^{\prime \prime} \mathrm{W}$ Long) on St. John's River, Beresford Peninsula, Florida. The more-than-6-ft-tall figurine was dredged from the muck of St. John's River. Coll. 1955 by a dragline operator supervised by Victor Roepke; subm. by R. P. Bullen, Florida State Museum, Cainesville, who has published a description of the object and its archaeological 
significance (1955). Comment: the figurine was correlated by Bullen on stylistic grounds as having been made during the Middle-Mississippi-influenced St. Johns II B Period. It is unique in heing the largest example of pre-Columbian woodcarving from Southeastern U. S.

\section{M-625. Kiawah Island, South Carolina}

$740 \pm 200$

Wood (Pinus taeda) from a 35-ft-long dugout canoe found on a small unnamed island in the marsh adjacent to Kiawah Island $\left(32^{\circ} 37^{\prime} \mathrm{N}\right.$ Lat, $80^{\circ} 02^{\prime}$ W Long), Charleston County, South Carolina. The island on which the canoe was located is considered to have formerly been part of Kiawah Island, being cut away from it during a hurricane tide. The canoe when found was covered with about $10 \mathrm{ft}$ of sand. Coll. 1956 and subm. by E. M. Burton, The Charleston Museum, Charleston, South Carolina.

\section{Chucalissa State Park series, Tennessee}

Charcoal from the Chucalissa State Park Site (3 Sy 1$)\left(35^{\circ} 04^{\prime} N\right.$ Lat, $90^{\circ} 08^{\prime} \mathrm{W}$ Long), Shelhy County, Tennessee. The site, which represents a fairly long Mississippian occupation, is composed of three strata. The lowest, Stratum 3, which varies in thickness from $6 \mathrm{in}$. to approximately $1 \mathrm{ft}$, is a midden deposit showing a heavy concentration of house-building activity. Above this is Stratum 2, the sterile clay loading of a mound construction. This is $5 \mathrm{ft}$ deep in some parts of the mound but very shallow in others. Stratum 1 is a heavy midden deposit extending $2 \mathrm{ft}$ above Stratum 2 and showing a series of superimposed floors. Coll. 1955-1958 and subm. by C. H. Nash, Tennessee Department of Conservation, Nashville.

\section{M-583. Chucalissa State Park ( 3 Sy 1), Stratum 3}

Specimen was in a shallow pit endin the midden deposit an shallow pit ending just ahove the skull of a burial in West and originating just below the floor of House \# 12. The specimen is to be associated with the top of Stratum 3 since House \#12 was immediately below the sterile clay loading of Stratum 2. The sample is therefore expected to date the initial occupation by a Mississippian group.

\section{M-789. Chucalissa State Park ( 3 Sy 1), Stratum 3}

Sample was collected as small particles of charcoal scattered between the floor of House \#12 and the sterile clay of Stratum 2. The date from this sample and that from M-583 hracket the construction of House \# 12.

\section{M-584. Chucalissa State Park (3 Sy 1), Stratum 1}

$510 \pm 200$

Charred log from floor of House \#3 at hottom of Stratum 1. Stratum 2 begins just below the house which is one of a series of superimposed floors in Stratum 1. The specimen is to be associated with the last period of occupation at the site. The associated artifacts are of Walls-Pecan Point assemblage.

\section{M-787. Chucalissa State Park (3 Sy 1), Stratum 1}

$350 \pm 200$

House $\#$ 3. This part of a large amount of charred material associated with House \#3. This specimen was collected a year after M-584 and was exposed to the atmosphere for the year prior to collection. 


\section{M-788. Chucalissa State Park ( 3 Sy 1 ), Stratum 1}

$360 \pm 150$

Sample was charred remains of post from post mold, a portion of the mound in which Stratum 2 was very shallow. The post mold, extending from a depth of $18.6 \mathrm{in}$. to $20.2 \mathrm{in}$., originated and associates with Stratum 1, but intruded through Stratum 2 to the top of Stratum 3. This sample, with M-584 and M-787, also dates the last period of occupation-Walls-Pecan Point assemblage.

\section{Russell Cave series, Alabama}

Charcoal from in and adjacent to Russell Cave $\left(34^{\circ} 58^{\prime} 37^{\prime \prime} \mathrm{N}\right.$ Lat, $85^{\circ}$ $48^{\prime} 32^{\prime \prime}$ W Long), Doran Cove, Jackson County, Alabama. The cave, as described by Broyles (1958) and Miller (1958), has heen extensively excavated. The samples included in this series cover a range from the earliest cultural manifestation so far uncovered to a Middle Woodland Occupation.

\section{M-557. Russell Cave, Middle Woodland}

$1110 \pm 200$

Coll. 1955 and sulm. hy Bettye Broyles, Illinois State Museum, Springfield. The charcoal came from a firepit in a level 4 to $5 \mathrm{ft}$ below the original ground surface. This sample was removed during the initial excavation of the site when the first $6 \mathrm{ft}$ of a continuous occupation zone was explored. Below the 6-ft level a thick sterile layer was uncovered. The sample dates the heginning of the use of limestone-tempered pottery of definite Middle Woodland type.

M-765. Russell Cave, Middle Woodland $\quad 1560 \pm 200$

Coll. 1957 and subm. by C. F. Miller, Smithsonian Institution, Washington, D. C. The specimen was found covering the torso of a male burial in a mound $100 \mathrm{yd}$ NNE of the cave. This burial, one of 12 found in the mound, was found at a depth of $4 \mathrm{ft} 2 \mathrm{in}$. in the mound. The burials were deposited over a period of time. No artifacts were found within the mound. The mound, one burial of which is dated by the sample, is interpreted as representing the terminal phase of occupancy of the Middle Woodland cultural group in this section of northern Alahama.

M-766. Russell Cave, earliest occupation $\quad 9020 \pm 350$

Coll. 1957 and subm. by C. F. Miller, Smithsonian Institution, Washington, D. C. The sample was taken from a hearth occurring next to the north wall of the cave at a depth of 23 ft below the present floor of the cave. The hearth was the earliest cultural manifestation uncovered as of 1957. Above the hearth a point with the outline of a Folsom fluted blade, hut lacking the fluting, was found. Comment: the first sample was collected independently of the latter two. It is thus difficult to correlate the interpretations given to the two samples (M557 and M-765) referring to Middle Woodland occupations. Other dates for Russell Cave have heen obtained from samples collected by Miller (Michigan II) . One of these, (M-591) coming from a level of $5.5 \mathrm{ft}$ from the present surface, was dated $6300 \pm 350$. The disparity between this date and that for M-557, above, which is indicated as coming from the 4- to 5-ft level, suggests that different datum lines were used by the two collectors. 


\section{Etowah series, Georgia}

Wood and shell specimens from the famous Etowah Site $\left(34^{\circ} 05^{\prime} \mathrm{N}\right.$ Lat, $84^{\circ} 50^{\prime} \mathrm{W}$ Long), $3 \mathrm{mi} \mathrm{S}$ of Cartersville, Bartow County, Georgia. This large Mississippi Culture Center in northwest Georgia is particularly important in determining the time period of the climax of Southeastern ceremonial activities (Kelly and Larson, 1957). Coll. June and October 1955; subm. by L. H. Larson, 735 West Avenue, Cartersville, Georgia. Additional samples will be run in the next few years.

M-402. Etowah, Burial 38

$\mathbf{7 2 5} \pm \mathbf{2 0 0}$

Wood sample (original no. 556) from a timber in the collapsed log tomb of Burial 38 of Mound C. This tomb lay under an extension of the final construction phase on the north side of the mound. A large amount of material of the Southeastern Ceremonial Complex was associated with the burial. The final construction phase falls within the Wilbanks ceramic period of the Etowah drainage.

\section{M-542. Etowah, Burial 57}

$910 \pm 200$

Juniper wood (original no. 862) which was part of a timber from the collapsed $\log$ tomb of Burial 57 under an extension of the next-to-the-last mantle on the north side of Mound C. This sample should date an embossed sheetcopper eagle-warrior plate found in the tomb.

M-543. Etowah, Burial 57

$\mathbf{5 0 0} \pm \mathbf{2 5 0}$

Shell beads (original no. 837) which were under the shoulders and around the neck of Burial 57 in a collapsed $\log$ tomb. Comment: the dates of this sample and of M-542 and M-402 should be very close.

\section{M-614. Sapelo Island, Georgia}

Oyster shells from Belleville Point bethind Modern Lat, $81^{\circ} 20^{\prime} \mathrm{W}$ Long). McIntosh County these shells came is probably the source of the oyster shells from the Sapelo prehistoric shell ring. Prehistoric oyster shells from this site, in a late Archaic level with plain fiber-tempered pottery, have been dated (M-39, average 3700 \pm 250 , Michigan I). The M-614 shells, which were shucked the last week of September 1956, were coll. by A. J. Waring, 113 E. Oglethorpe Avenue, Savannah, Georgia, and subm. by him to test the accuracy of M-39 in determining the age of this pottery level on the Georgia coast. Since their $\mathrm{C}^{14}$ content does not differ significantly from that of our wood standard, we have not corrected for isotopic fractionation in expressing the age of this and other contemporary shell samples (see M-574, M-726, M-727B).

\section{1). II estern and Southwestern l' niled State's}

\section{M-286. Blue Mountain Site A:10:7, Colorado}

Corn cobs identified as "Mexican-like" Dent Type from shallow cave in Southern Blue Mountain $\left(40^{\circ} 15^{\prime} \mathrm{N}\right.$ Lat, $108^{\circ} 40^{\prime}$ W Long), Moffat County, Colorado. The cobs were taken from an 18-in. test pit 32 in. below the cave floor surface. The maximum depth where tested was 36 in. The artifacts from the cave indicate the dated assemblage to be a representative of the Fremont 
culture. Coll. 1950 and subm. by G. R. Wenger, U. S. National Park Service, who has published a summary of the archaeology of the Southern Blue Mountain (in Wormington, 1955, p. 140-142).

M-551. Old Woman Site, Utah

$1060 \pm 200$

Charred pinyon pine wood from the Old Woman Site $\left(38^{\circ} 44^{\prime} \mathrm{N}\right.$ Lat, $111^{\circ} 25^{\prime} 30^{\prime \prime} \mathrm{W}$ Long), Wasatch Plateau, Sevier County, Utah. The sample was obtained from the collapsed roofing timbers on the floor of a semi-subterranean house. The timbers were 21 to 27 in. below the surface, underlying roof debris and water- and wind-filled deposits. The associated artifacts included "Fremont" anthropomorphic figurines and Turner Gray Pottery. Coll. 1955 and subm. by Dee C. Taylor, Montana State University, Missoula, who has published (1957) an analysis of this site and that from which M-552 (below) was obtained.

\section{M-552. Poplar Knob Site, Utah}

$1170 \pm 250$

Charred pinyon pine wood from the Poplar Knob Site $\left(38^{\circ} 44^{\prime} \mathrm{N}\right.$ Lat, $111^{\circ} 25^{\prime} 30^{\prime \prime} \mathrm{W}$ Long), Wasatch Plateau, Sevier County, Utah. The sample was probably the remains of a roofing timber from House \#1, one of the three adobe and masonry structures at the site. The sample was lying on the floor of the house, $3.75 \mathrm{ft}$ below the surface, under collapsed roof debris and fill material of water- and wind-deposited sand and clay. Associated artifacts included Turner Gray pottery and coiled basketry. Coll. 1955 and subm. by Dee C. Taylor, Montana State University, Missoula.

\section{M-616. Blossom Site, California}

$\mathbf{3 0 8 0} \pm \mathbf{3 0 0}$

Calcined human bone from a cremation in the Blossom Site $\left(38^{\circ} 14^{\prime} 30^{\prime \prime}\right.$ $\mathrm{N}$ Lat, $121^{\circ} 26^{\prime} 50^{\prime \prime}$ W Long), San Joaquin County, California. The site from which the sample was obtained is a single-phase mound site stratified into three layers. The mound mass is composed of about $6 \mathrm{in}$. of loose topsoil cover, 12 to 18 in. of "occupational hardpan," and about 65 in. of accumulated refuse. It is in this last layer that most of the burials or cremations are found and from which the sample was obtained. The site is of the Early Horizon, Windmiller culture (see Heizer, 1949). Coll. 1949 and subm. by R. F. Heizer, University of California, Berkeley. Comment: other radiocarbon dates have been obtained for this site (see Michigan III, and Heizer, 1958). Samples M-645, 4100 \pm 250 , and M-647, 4350 \pm 250 , are considered more reliable estimations of the age of this site than is this sample. Previous samples, C- 440 and C-552, averaging $4052 \pm 160$, Chicago I, agree with this interpretation.

M-7.42. 18 Mile Bend Site, New Mexico

$850 \pm 200$

Wood. prohably Juniper (id. by A. J. Jelinek). Crom the 18 Mile Bend Site $134^{\circ} 14^{\prime} \mathrm{N}$ Lat, $104^{\circ} 13^{\prime} \mathrm{W}$ Long), Middle Pecos River Valley, New Mexico. The sample was obtained from one of four major roof supports of a surface structure suggesting a pit-house in floor plan. The structure was associated with a bison-hunting cultivation economy of the last period of sedentary occupation of the Middle Pecos Valley. Cultural associations were determined on the basis of associated pottery. The date apparently confirms the previous correlation of this material (Middle Pecos III) with late Pueblo III of the 
Anasazi area. Coll. 1957 and sulm. by A. J. Jelinek, Beloit College, Beloit, Wisconsin, who has published a description of the archaeology of the area (1958).

\section{M-752. Roeder Site, California}

$1750 \pm 500$

Charred wood and basketry from the Roeder Site $\left(38^{\circ} 31^{\prime} \mathrm{N}\right.$ Lat, $121^{\circ}$ $31^{\prime}$ W Long), Sacramento County, California. The sample is from the gravepit burning of Burial 123, found at a depth of 111 in. in this stratified, multiphase deposit. The burial offering represents the terminal phase of the Middle Horizon culture, and the earliest occurrence yet known of gravepit burning. Coll. 1956 by B. Arnold; subm. by J. A. Bennyhoff, Yale University. Comment: an age of 2000 to $2500 \mathrm{yr}$ ago was expected for this sample. The basketry was sprayed with the preservative "Krylon" which is an organic substance. Contamination may therefore have affected the date. The wood portion of the sample was not so treated.

\section{M-811. Lehner Mammoth Site, Arizona}

$11,290 \pm 500$

Mixed pine, ash, and oak charcoal from the Lehner Mammoth Site $\left(31^{\circ}\right.$ $25^{\prime} 23^{\prime \prime} \mathrm{N}$ Lat, $110^{\circ} 06^{\prime} 48^{\prime \prime} \mathrm{W}$ Long), Cochise County, Arizona. The sample was taken from the second of two hearths on a sand har in association with an extensive deposit of bones and considerable cultural material. The hearth was buried under fine sand, swamp soil. silts grading to clayey silt-post-Altithermal and recent deposits-to a depth of about $3 \mathrm{~m}$. The fauna represented in the bone deposits included nine young mammoths and bone elements of horse, bison, and tapir. The associated cultural material included thirteen Clovis fluted points and eight cutting and scraping tools presumed to have heen used in butchering. Coll. 1956 by W. W. Wasley; subm. by E. W. Haury, University of Arizona, Tucson, who has published a description of the site (1958). Comment: six other dates have been obtained from samples from this site (Arizona I). Four of these, processed in 1956, yielded dates ranging from $6356 \pm 450$ (A-31), to $8330 \pm 450$ (A-30). The two other samples (A-40a and A40b), which were processed in 1957, gave datings of $12,000 \pm 450$ and $10,900 \pm 450$ respectively. One additional date is mentioned by Haury (personal communication, May, 1958). This is an assay from the Copenhagen laboratory giving a date of $11,180 \pm 140$. The agreement of the two oldest Arizona dates with those from Copenhagen and Michigan and with the expected age of Clovis material suggests that the other Arizona dates are too young.

\section{E. Mexico and South America}

\section{M-719A, B. Cozumel Island, Mexico}

$719 \mathrm{~A} \quad 200 \pm 200$

$719 B \quad 180 \pm 200$

Wood section of a vault beam from Structure 3, San Gervasio $\left(20^{\circ} 31^{\prime} \mathrm{N}\right.$ Lat, $86^{\circ} 54^{\prime}$ W Long), Cozumel Island, Yucatan, Mexico. The beam was in situ in a presumably "Late" Maya masonry building, Structure 3, of Sanders (1955). The date for M-719A was obtained from the outer section of the beam while M-719B is from the core of te beam. Coll. 1955 by L. M. Hewen; subm. 
by the University Museum of Pennsylvania. Comment: the two dates are probably too recent.

\section{M-857. Dzibilchaltun, Mexico}

Wood ("subinche") from a lintel over the doorway of the Temple of the Seven Dolls, Dzibilchaltun $\left(21^{\circ} 15^{\prime} \mathrm{N}\right.$ Lat, $89^{\circ} 30^{\prime} \mathrm{W}$ Long), Yucatan, Mexico. The sample dates the construction of temple (Andrews, 1959, p. 107). In this article the A.D. 458 cited is M-857 while another still unidentified radiocarbon laboratory obtained a measurement cited as A.D. 508 with the same margin of error of $200 \mathrm{yr}$. Both measurements were from the same beam. Coll. 1958 by E. W. Andrews; subm. by L. J. Briggs, National Ceographic Society, Washington, D. C. Comment: there is close agreement.

\section{M-861. EI Ticuiz, Mexico $\quad 1420 \pm 200$}

Fresh- and salt-water molluses from El Ticuiz $\left(18^{\circ} 40^{\prime} 40^{\prime \prime} \mathrm{N}\right.$ Lat, $103^{\circ}$ $42^{\prime} 30^{\prime \prime} \mathrm{W}$ Long), Municipio Coahuayana, Michoacan, Mexico. The shells include the following: Lithophagus plumula, Polymesoda radiata, and Tagelus affinis longisinuatus. These specimens are from a kitchen midden at a depth of $10 \mathrm{in.} \mathrm{located} \mathrm{on} \mathrm{a} \mathrm{fossil} \mathrm{or} \mathrm{elevated} \mathrm{beach} \mathrm{which} \mathrm{apparently} \mathrm{had} \mathrm{been} \mathrm{used} \mathrm{as}$ a prehistoric house site. Pottery, shells, and sandy loam were in the deposit. The species are similar to those from an archaeological mound on the opposite side of the Rio del Ticuiz which were obtained in 1956. Coll. July 3, 1957 and subm. by D. D. Brand, University of Texas, Austin.

\section{M-592. Schroeder Site (LChap AJ1-1), Mexico $\quad 1150 \pm 200$}

Charred wood which was associated with charred corn cobs from the Schroeder Site $\left(23^{\circ} 55^{\prime} 17^{\prime \prime}\right.$ N Lat, 104 ${ }^{\circ} 44^{\prime} 35^{\prime \prime}$ W Long), Durango, Mexico. Sample was obtained from an ashy deposit at the base of the north wall of the Northwest Platform of the Structure 7 complex. The ashy deposit occupied an area about $60 \mathrm{~cm}$ in diameter and was on top of a slab of rhyolite which showed the effects of a fire on its upper surface. The ashy deposit extended at least $30 \mathrm{~cm}$ under the foot of the north wall of the Northwest Platform and, accordingly, must have been deposited before the construction of this architectural feature. The soil ahove the sample and the fill of the NW Platform both contained sherds of decorated pottery such as Amaro Red-on-Cream, Mercado Redon-Cream, and Suchil Engraved, indicating that these deposits pertain to the Ayala Phase of the Chalchihuites culture. There is little indication anywhere in the Structure 7 area of material of the preceding Alta Vista Phase, so that the charcoal itself should pertain to the Ayala Phase, which is tentatively dated from A.D. 450 to 700. Coll. August 1956 by H. D. Winters and J. E. Loomis; subm. by J. C. Kelley, Southern Illinois University, Carbondale. Comment: another date from this site has been published (Michigan III, p. 1120) as M-613, $1550 \pm 250$.

\section{Huapalcalco series, Hidalgo, Mexico}

Charred wood from Mound VI of the archaeological zone of Huapalcalco $\left(20^{\circ} 7^{\prime} 30^{\prime \prime} \mathrm{N}\right.$ Lat, $98^{\circ} 22^{\prime} 30^{\prime \prime} \mathrm{W}$ Long), $4 \mathrm{~km} \mathrm{~N}$ of Tulancingo, Hidalgo, Mexico. 
M-611. Huacapulco, floors 1 to 5

$1650 \pm 200$

Fragments of carbonized wood associated with artifacts collected from under floors 1 to 5 . The artifacts correspond to the phases of Teotihuacan I and Ticoman III of the Preclassic of the Valley of Mexico. Coll. December 24, 1955 and May 24, 1956 by E. F. Jacobs Müller and C. Lizardi Ramos; subm. by E. F. Jacobs Müller, Instituto Nacional de Antropología y Historia, Mexico.

M-612. Huacapulco, tomb

$1950 \pm 200$

Charred sample from the south end of one of the crosspoles which held up the stone slab roof of the tomb of burial B. This material was found lying on floor 8 under seven other sealed floors which were on the top of Mound VI. The burial was associated with five vessels which correspond to Ticoman II of the Valley of Mexico Preclassic. The absence of Teotihuacan I artifacts suggests that material of this type did not arrive at this site until the end of the Preclassic. Comment: these dates are somewhat later than might have been expected for the late Preclassic.

\section{M-734. Tarqui Site, Ecuador}

$2170 \pm 200$

Wood charcoal at a depth of $7 \mathrm{ft} 2 \mathrm{in}$. in a single period deposit of $15 \mathrm{in}$. depth of the Tarqui Site $\left(0^{\circ} 57^{\prime} \mathrm{S}\right.$ Lat, $80^{\circ} 43^{\prime}$ W Long $)$, Manabi Province, Ecuador. This site near the town of Manta represents what Emilio Estrada has called the Bahia de Caraquez culture. The deposit shows no discernible cultural change from top to bottom (Estrada, 1957; Saville, 1910). Coll. April 13, 1957 and subm. by M. W. Stirling, Smithsonian Institution, Washington, D. C.

\section{M-735. La Tolita, Ecuador}

$1690 \pm 200$

Wood charcoal from within a pottery-tube burial typical of the Atacames culture from La Tolita $\left(1^{\circ} 12^{\prime} \mathrm{N}\right.$ Lat, $79^{\circ} \mathrm{W}$ Long), Esmeraldes Province, Ecuador. This is perhaps the most famous site in Ecuador. The material bears a strong resemblance to that of Mexican and Central American cultures. The site has never been worked scientifically, and probably several periods are represented (Saville, 1910; Rowe, 1949). Coll. April 29, 1957 and subm. by M. W. Stirling, Smithsonian Institution, Washington, D. C.

\section{M-736. Cerro de Hojas, Ecuador}

$560 \pm 200$

Wood charcoal at a depth of $3 \mathrm{ft}$ in the middle of one of the stone "corrals" typical of Cerro de Hojas ( $1^{\circ} 2^{\prime} \mathrm{S}$ Lat, $80^{\circ} 29^{\prime} \mathrm{W}$ Long), Manabi Province, Ecuador. This is one of the famous "stone seat" sites examined by Saville in 1907 (Saville, 1910; Estrada, 1957). The associated pottery is now known to belong to the Manteño culture. Coll. April 3, 1957 and subm. by M. W. Stirling, Smithsonian Institution, Washington, D. C., who is preparing a report on the collections from the three Ecuadorian sites.

\section{M-510. Cliza, Bolivia}

$1680 \pm 300$

Charcoal from Cliza ( $17^{\circ} 32^{\prime} \mathrm{S}$ Lat, $65^{\circ} 52^{\prime} \mathrm{W}$ Long, $2730 \mathrm{~m}$ alt.) in layer 7 of the Cliza habitation mound, Bolivia, at a depth of $3 \mathrm{~m}$. This sample is from levels of the Pre-Tiahuanaco Expansive Epoch in the Cochabamba area. It was taken from beside a ruined adobe wall which had been burned. The wall corresponded to the seventh stratum of ash from the top. 
Coll. November 1955 by D. E. Ibarra Grasso; subm. by Carlos Ponce Sanginés, Bolivian Foreign Service, La Paz, Bolivia. Comment: this run was made on a small sample but corresponds to the estimate of 0 to A.D. 500 .

M-509. Omereque, Bolivia

$\mathbf{9 0 0} \pm \mathbf{2 0 0}$

Organic remains including fabric from the interior of a skull in a rock shelter near Omereque (ca. $17^{\circ} 50^{\prime} \mathrm{S}$ Lat, $65^{\circ} 20^{\prime} \mathrm{W}$ Long), Campero Province, Cochabamba Dept., Bolivia. In this same tomb were found Tiahuanaco vessels and textiles of the Expansionist Period which would be Bennett's (1936, p. 375-389) Arani I phase which he dated A.D. 1000 (Bennett 1946, p. 80). Coll. November, 1955 by D. E. Ibarra Grasso; subm. by Carlos Ponce Sanginés, Bolivian Foreign Service, La Paz, Bolivia.

\section{F. North Pacific}

\section{Amaknak-D series, Dutch Harbor, Aleutian Islands}

Charcoal, wood, and humus from the Amaknak-D Site $\left(53^{\circ} 53^{\prime} 6^{\prime \prime} \mathrm{N}\right.$ Lat, $166^{\circ} 33^{\prime} 36^{\prime \prime} \mathrm{W}$ Long), Unalaska Bay, Dutch Harbor Island. These samples are a part of a large series coll. and subm. by T. P. Bank II, University of Michigan, Ann Arbor (1953, 1954), which will be described in his report in progress.

\section{M-676. Amaknak 714}

$1880 \pm 200$

Charcoal (Orig. no. Amak-714) from mixed humus and fish bone stratum at 181 in. below datum which is ca. 30 in. above lowest cultural level in NW Quad., Sec. 1, Shelf area. Associated with broad-headed Aleut skeletal type. This sample gives an unexpectedly early date for the replacement of the socalled "Paleo-Aleut" type by the "Aleut". Coll. September 9, 1951.

M-677. Amaknak 736

$1450 \pm 200$

Charcoal which was part of a hearth feature in Sec. 1 shelf at 140 in. below datum in the lower $3 / 4$ of the site (Orig. no. Amak-736). Dates the beginning of several cultural changes in the site; e.g., the first appearance of rich art. Coll. September 10, 1951.

\section{M-678. Amaknak $\mathbf{5 4 8}$}

$1470 \pm 200$

Driftwood (Populus) used as house support in humus and mussel shell at 121 in. below datum in SE Quad., Sec. 2 (Orig. no. Amak-548). Associated with large whale bone and considerable chipped stone. Coll. September 4, 1951.

\section{M-681. Amaknak 374}

$1100 \pm 250$

Wood (Alaskan cedar) in humic and sea-urchin-shell layer at $100 \mathrm{in}$. below datum, E Quad., Sec. D, in the middle level of the site (Orig. no. Amak374). Part of a burial complex with a flexed broad-headed Aleut covered with considerable whale bone, blackened (by fire?) flat stones covering the burial, and the wood, also apparently part of the mortuary covering. Coll. August 28, 1951.

\section{M-682. Amaknak 351}

$\mathbf{1 5 8 0} \pm \mathbf{2 5 0}$

Humus with charcoal (?) and herbaceous plant matter in clay muck with clam shell in SW Quad., Sec. C, at 58 in. below datum. This sample was im- 
mediately under a broad-headed Aleut skeleton (burial I-1) (Orig. no. Amak351). Coll. August 26, 1951.

\section{M-690. Michigan Rock Cave, Aleutians $\quad 100+200$}

Driftwood (Populus) in cave debris on small islet off Tanaga Island $\left(51^{\circ}\right.$ $41^{\prime} \mathrm{N}$ Lat, $178^{\circ} 01^{\prime} 50^{\prime \prime} \mathrm{W}$ Long), in the Lash Bay area, Aleutian Islands. From Sec. 4 at ca. $2 \mathrm{ft}$ depth in humus (?), shell, and rock (Orig. no. MR-1 (X) ). Coll. August 18, 1950 and subm. by T. P. Bank II, University of Michigan, Ann Arbor. Comment: cave serevly disturbed during World War II. Date, if accurate, marks the westernmost extension of human "mummification" hy Aleuts. Considerable grass-woven "mummy" matting found with burials. Probably, mummification did not reach middle and western Aleutians until just hefore historical period (174.1), as indicated by this date.

\section{M-692. Kismaliuk Rock Shelter, Aleutians $\quad 650 \pm 200$}

Wood (Populus) from site located on west side of Kismaliuk Point on the north shore of Unalaska Island $\left(53^{\circ} 28^{\prime} 12^{\prime \prime} \mathrm{N}\right.$ Lat, $167^{\circ} 18^{\prime} 30^{\prime \prime} \mathrm{W}$ Long), Aleutian Islands. The sample is from lance shafts covering human burials of the broad-headed, recent Aleut type at $2 \mathrm{ft}$ below the surface of Sec. 3 (Orig. no. Ka-21-26). Date agrees well with nearby Split Rock Cave. Coll. August 18, 1954 and subm. by T. P. Bank II, University of Michigan, Ann Arbor.

\section{M-693. Split Rock Cave, Aleutians $\quad 700 \pm 300$}

Wood (Alaskan cedar or Populus) from cave on west side of Split Rock (Kashega Rock) (53 $29^{\prime} 06^{\prime \prime}$ N Lat, $167^{\circ} 18^{\prime} 54^{\prime \prime}$ W Long), off northern Sedanka Point on the north side of Unalaska Island. Burials, artifacts, and wood found in humus in the rear of cave at a depth of $1.5 \mathrm{ft}$. This is the cave visited by the Stoll-McCracken expedition of 1928 and is the location of mummies found by that party (Weyer, 1929). Date agrees well with that for nearby Kismaliuk shelter as well as for dates on the mummy caves at Kagamil Island (M-92, $900 \pm 300 ;$ M-94, $980 \pm 250$, Michigan I). Coll. August 17, 1954 and subm. by T. P. Bank II, University of Michigan, Ann Arhor.

\section{Boldanig House Mound series, Yap}

Charcoal from the site of Boldanig House Mound $\left(09^{\circ} 35^{\prime} \mathrm{N}\right.$ Lat, $138^{\circ}$ $10^{\prime}$ E Long), Malaj Village, Kanifay municipality, Yap. Coll. 1956 and subm. by E. W. Gifford, Inniversity of California, Berkeley.

\section{M-791. Boldanig House Mound, 60 to 66 in. deep}

Sample associated with potsherds and other artifacts.

\section{M-792. Boldanig House Mound, 54 to 60 in. deep}

$$
100 \begin{array}{r}
+200 \\
-100
\end{array}
$$

Sample associated with potsherds and other artifacts. Comment: other radiocarbon dates from Yap from material obtained by Gifford, including one for this same site, have been published in Michigan III. The previous sample 
from the Boldanig House Mound (M-631) was from the 30- to 42-in. level and dated $320 \pm 200$. Gifford will discuss the archaeology of Yap in an article to be published in 1959.

M-666. Waiahukini, Hawaii

$1000 \pm 200$

Charcoal from bottom of cultural deposit in Waiahukini Shelter, Site H 8 , Kau ( $18^{\circ} 57^{\prime} \mathrm{N}$ Lat, $155^{\circ} 42^{\prime} \mathrm{W}$ Long), Hawaii. The sample came from 25 to 27 in. below the surface in sq. D10-D11. Fisherman's shelter is a lava tube yielding over 800 fishhooks evenly distributed stratigraphically, hence a control site for the period of its use. Coll. December 28, 1956 by W. J. Bonk; subm. by K. P. Emory, Bishop Museum, Honolulu, who has a publication in preparation.

\section{M-667. Hayes Cave, Hawaii}

$\mathbf{2 0 0} \pm \mathbf{1 5 0}$

Charcoal from Site H 51, Kiilae, South Kona $\left(19^{\circ} 24^{\prime} 45^{\prime \prime}\right.$ N Lat, $155^{\circ}$ $54^{\prime}$ W Long), Hawaii. Sample is from a surface hearth on the floor of refugee cave, upper tube, east juncture of north and south Keokea tube. Coll. February 9, 1957 and subm. by K. P. Emory, Bishop Museum, Honolulu. Comment: proves use of cave after establishment of City of Refuge (Honaunau) $1 \mathrm{mi}$ distant.

\section{M-767. Moomomi Shelter, Hawaii}

$\mathbf{5 5 0} \pm \mathbf{3 0 0}$

Charcoal from 45 in. below surface at the bottom of the cultural deposit in Moomomi Shelter, Site Mo. 1, West Molokai $\left(21^{\circ} 12^{\prime} \mathrm{N}\right.$ Lat, $157^{\circ} 9^{\prime} 30^{\prime \prime}$ W Long), Hawaii. Coll. July 1952 by W. J. Bonk; subm. by K. P. Emory, Bishop Museum, Honolulu.

\section{M-863A. Puu Alii, Hawaii}

$580 \pm 150$

Charcoal from Puu Alii, Site H 1, South Point, Kau ( $18^{\circ} 54^{\prime} 45^{\prime \prime}$ N Lat, $155^{\circ} 41^{\prime} \mathrm{W}$ Long), Hawaii. The sample is from a hearth 18 to 21 in. below top of cultural stratum buried under a sand dune in sq. J-11. Coll. October 18, 1953 by W. J. Bonk; subm. by K. P. Emory, Bishop Museum, Honolulu. Comment: according to Emory the hook types immediately above the hearth compare with those of the very bottom of the Waiahukini shelter of M-666 (1000 $\pm 200)$. Therefore, as with the other two samples tested from the beginning of the occupation of this site (M-479, $200 \pm 200 ;$ M-538, <200, Michigan II), contamination appears to cause these specimens to date later than their true age according to our interpretation.

\section{M-863B. Waiahukini, Hawaii}

$730 \pm 200$

Charcoal from Waiahukini Shelter, Site H 8, Kau $\left(18^{\circ} 57^{\prime} \mathrm{N}\right.$ Lat, $155^{\circ}$ $42^{\prime} \mathrm{W}$ Long), Hawaii. The sample was taken from a level 17 to 21 in. below the surface in sq. F 5. It was stratigraphically above the sample (M-666, above) obtained from the 25- to 27-in. level in an adjacent area. The agreement of these two dates with their stratigraphic position suggests their reliability. The later date of $730 \pm 200$ marks the upper limit of a clearly defined cultural period. Coll. 1956 by W. J. Bonk; subm. by K. P. Emory, Bishop Museum, Honolulu. Emory has a publication dealing with this site in preparation. 


\section{G. South Pacific}

M-7 11. Vinapu, Easter Island

$730 \pm 200$

Charred human bone from crematorium of ceremonial center of Vinapu $\left(27^{\circ} 32^{\prime} \mathrm{S}\right.$ Lat, $109^{\circ} 17^{\prime} \mathrm{W}$ Long), Easter Island. Crematorium from which sample was taken is just to seaward of Ahu \#l (see below, M-732). The date established that cremation activities and the structure were part of the Epoch II occupation of the site. Coll. December 1955 by W. Mulloy, University of Wyoming; subm. by him for Thor Heyerdahl. Comment: Mulloy will prepare the report on the excavation and significance of the site. For other dates from

Vinapau: (M-709, $120 \begin{array}{r}+260 \\ -120\end{array} ;$ M-710, $1100 \pm 200$, Michigan III $)$.

\section{M-732. Ahu Tepeu, Easter Island}

$1640 \pm 250$

Totora reeds, dry and unburned, from north coast of Easter Island $\left(27^{\circ}\right.$ $08^{\prime} 06^{\prime \prime}$ S Lat, $109^{\circ} 25^{\prime} 54^{\prime \prime}$ W Long). From Ahu \# 1, Ahu Tepeu Site (E-13). Ahu Tepeu is a masonry structure embodying three stages of construction. Grave \# 2 belongs to either the first or second period of construction. The reeds were directly associated with the skeletons of nine individuals in a stone chamber without earth fill, buried under stone masonry and a fallen statue. The chamber and its contents helongs either to Period I or Period II in the construction of the Ahu. Elsewhere on Easter Island such chambers correlate with the second period which falls between (a. 250 to 850 B.P. Coll. December 19 , 1955 by Carlye S. Smith, University of Kansas, Lawrence; subm. by him for Thor Heyerdahl. Comment: Smith is preparing a report on this site and by then Michigan will have run fresh totora reeds to test their $\mathrm{C}^{14}$ age. Smith helieves that a possible source of error is that these reeds grow only in freshwater lakes within the confines of three volcanic craters.

\section{M-727A. Bato Caves, Philippines $\quad \mathbf{2 2 8 0} \pm \mathbf{2 5 0}$}

Sea shells represented by two species, Strombus isabella and Arca capoides, from Bato Jar-Burial Cave \# 1, Sorsogon Province ( $13^{\circ} 01^{\prime} \mathrm{S}$ Lat, $124^{\circ} 06^{\prime} \mathrm{E}$ Long), Philippines. The shells were found as food offerings in large earthenware burial jars. Coll. August 1956 and subm. by R. B. Fox, University of the Philippines, Quezon City. Comment: the Bato Caves provide for Philippine archaeology the first unquestionable instance of an association of pottery and stone tools; a pre-iron site. Eleven caves with an identical assemblage of materials have been found in the Allay Gulf area, and this "culture" is called the Circum-Albay Gulf, Stone Tool and Jar Burial Assemblage (Fox and Evangelista, 1957).

\section{M-728. Bato Caves, Philippines}

Sea shells represented by Strombus isabella and Arca capoides from Cave \#2, Sorsogon Province, at the same location as M-727A. The shells were found in a small, unstratified midden at the mouth of Cave \#2. Coll. August 1956 and subm. by R. B. Fox, University of the Philippines, Quezon City.

\section{M-727B. Sugod Bay, Philippines $\quad \mathbf{5 0 0} \pm \mathbf{2 0 0}$}

Live sea shells of Strombus isabella and Arca capoides coll. along the shores of Sugod Bay, Sorsogon Province, some $550 \mathrm{~m}$ from the Bato Caves 
$\left(13^{\circ} 01^{\prime} \mathrm{S}\right.$ Lat, $124^{\circ} 06^{\prime} \mathrm{E}$ Long) to provide a control on the shell samples from the caves. Comment: it should be noted that the apparent ages of the three samples M-727A, 728, and $727 \mathrm{~B}$ were calculated with reference to modern wood as a standard, without correction for possible isotope fractionation in the shell. If the result of M-727B is taken for modern, and is applied to $\mathrm{M}-727 \mathrm{~A}$ and 728,500 years should be subtracted from the ages stated for $727 \mathrm{~A}$ and 728.

\section{References}

Arizona I. Wise and Shutler, 1958

Chicago I. Arnold and Libby, 1951

Chicago III. Libby, 1952

Chicago V. Libby, 1954

Michigan I. Crane, 1956

Michigan II. Crane and Griffin, 1958a

Michigan III. Crane and Griffin, 1958b

Yale IV. Deevey, Gralenski, and Hoffren, 1959

Allman, J. C., 1957, A new late Woodland culture for Ohio: Ohio Archaeologist, v. 7, p. 59-68. W 1959 Dribilchaltun: lost city of the Maya: Nat. Geog. Mag., v. 115, 1. Andrews, $90-109$.

Arost Science, v. 113, p. $111-120$

Bank, T. P., II, 1953, Cultural succession in the Aleutians: Am. Antiquity, v. 19, no. 1, p. $40-49$. 1954, Archaeological field
5th, Anchorage 1954, Proc., p. 94.

Bennett, W. C., 1936, Excavations in Bolivia: Am. Mus. Nat. History Anthropol. Papers, v. 35 , pt. 4 , p. $329-507$

1946, The archaeology of the Central Andes. Handbook of the South American Indians, v. 2: Bur. Am. Ethnology Bull. 143, p. 61-147.

Broyles, Bettye, 1958, Russell Cave in northern Alabama. Tennessee Archaeol. Soc. Misc. Paper 4, $35 \mathrm{p}$.

Bullen, R. P. 1955, Carved owl totem, DeLand, Florida: Florida Anthropologist, v. 8, no. 3 , p. $60-73$.

Byers, D. S., 1954, Bull Broook-a fluted point site in Ipswich, Massachusetts: Am. Antiquity, v. 19 , p. $343-351$.

Aituly, Arotl Brook site, Massachusetts: Am. Antiquity, v. 20 , p. $274-276$.

1956, Tpswich B. C.: Essex Inst. Hist. Coll., v. 92, p. 252-264.

Crane, H. R., 1956, University of Michigan radiocarbon Michigan radiocarbon dates II: S. ience, v. 127, p. 1098-1105. 1123.

Deevey, E. S., Gralenski, L. J., and Hoffren, Väinö, 1959, Yale natural radiocarbon meas-

urements: Am. Jour. Sci. Radioc. Supp., v. 1, p. 144-172.
Deuel, Thorne, ed., 1952, Hopewellian communities in Illinois: Illinois State Mus. Sci.

Papers, v. 5, 271 p.
Dickson, D. F., 1956, The Liverpool Mounds: Central States Archaeol. Jour., v. 2, no. 3 , p. 85-92.

Eldridge, W. A., and Vaccaro, Joseph, 1952, The Bull Brook Site, Ipswich, Massachusetts: Massachusetts Archaeol. Soc. Bull., v. 13, p. 39-43.

Estrada, V. E., 1957, Prehistoría de Manabi: Mus. Víctor Emilio Estrada Pub. 4, 176 p.

Fox, R. B., and Evangelista, Alfredo, 1957, The Bato Caves, Sorsogon Province, Philippines; a preliminary report of a jar burial-stone tool assemblage: Univ. Manila Jour. East Asiatic Studies, v. 6, no. 1, p. 49-55.

Gifford, E. W., and Gifford, D. S., in press, Archaeological excavations in Yap: Univ. California Anthropol. Recs., v. 18.

Griffin J. B 1958, The chronological position of the Hopewellian culture in the Eastern United States: Univ. Michigan Mus. Anthropology, Anthropol. Papers 12, $27 \mathrm{r}$. 
Guthe, A. K., 1958, The Morrow site: Eastern States Archaeol. Fed. Bull. 17, p. 11. Hall, R. L., 1958, Commentary on Carcajou carbon-14 dates: Wisconsin Archeologist, v. 39,
no. 3, p. 174-175.

Univers., Carcajou Point and the problem of Oneota origins: Ph.D. dissertation,

Hamilton, H. W., 1952, The Spiro Mound. With preface and appendix by J. B. Griffin:
Missouri Archaeologist Missouri Archaeologist, v. 14, $276 \mathrm{p}$.

mammals of New York S. C., 1921, The mastodons, mammoths, and other Pleistocene mammals of New York State: New York State Mus. Bull., nos. 241-242, p. 7-110.

Haury, E. W. 1958, Two fossil elephant kill sites in the American Southwest: Univ. Arizona, Program in Geochronology, Contr. 4. Internat. Cong. Americanists, 32nd, Copenhagen 1956, Proc., p. 433-440.

Heizer, R. F., 1949, The archaeology of central California, I: the early horizon: Univ. California Anthropol. Recs., v. 12, no. 1, iii, 74 p.

California Archaeol. Survey Repts. 44, i, 51 dates from California and Nevada: Univ.

Hurt, W. R., 1953, Report of the investigation of the Thomas Riggs Site, 39HU1, Hughes County, South Dakota: South Dakota Archaeol. Comm. Archaeol. Studies, Circ. 5,

Mexico: Jin 1958, Archaeological materials from the Middle Pecos River Valley, New

Mexico: Michigan Acad. Sci., Arts, and Letters, Papers, v. 43, p. 159-168.

and Archaeology, no. 27 Serpent Mounds site, 1957: Royal Ontario Mus. Bull. Div. Art and $1958 \mathrm{~b}$, no. 27 , p. 3-7.

1958b, The findings after two years of work at Serpent Mounds site, Rice

Cartersville, Georgia 1954-1956: Archaeogy

Cartersvile, Georgia 1954-1956: Archaeology, v. 10, p. 39-48

Lawrence, D. B., 1936, The submerged forest of the Columbia River Gorge: Geog. Rev.,

Libby, W. F., 1952, Chicago radiocarbon dates, III: Science, v. 116, p. 673-681.

1954, Chicago radiocarbon dates V: Science, v. 120, p. 733-742.

1955, Radiocarbon dating, 2nd ed.: Chicago, University of Chicago Press, 175 p.

Miller, C. F., 1958, Russell Cave: new light on stone age life. The Nat. Geographic, v. 113, no. 3 , p. $426-437$.

Neumann, G. K., and Fowler, M. L., 1952, Hopewellian sites in the lower Wabash Valley, in Deuel, Thorne, ed., Hopewellian communities in Illinois: Illinois State Mus. Sci. Papers, v. 5, no. 5, p. 177-248.

Ritzenthaler, Robert, ed., 1957, The Old Copper Culture of Wisconsin: Wisconsin Archeologist, v. 38, new ser., no. 4, p. 185-332.

Roedl, L. J., and Howard, J. H., 1957, Archaeological investigations at the Renner Site: Missouri Archaeologist, v. 19, no. 1-2, p. 52-90.

Rowe, C. W., 1958, A crematorium at Aztalan: Wisconsin Archeologist, v. 39, no. 1, p. 101 110.

Rowe, J. H., 1949, The potter's art of Atacames: Archaeology, v. 3, no. 1, p. 31-34

Sanders, W. T., 1955, An archaeological reconnaissance of northern Quintana Roo: Carnegie Inst. Washington Div. Archaeology, Current Repts., v. 2, no. 24, p. 179-222.

Saville, M. H., 1910, The antiquities of Manabi, Ecuador: final report: Mus. Am. Indian, Heye Foundation Pub., Contr. South Am. Archeology, v. 2.

Smith, H. G., 1951, The Crable Site, Fulton County, Illinois: a late prehistoric site in the central Illinois Valley: Univ. Michigan Mus. Anthropology, Anthropol. Papers 7, 53 p.

Taylor, Dee C., 1957, Two Fremont sites and their position in Southwestern prehistory: Univ. Utah Anthropol. Papers 29, xi, 185 p.

Wedel, W. R., 1943, Archeological investigations in Platte and Clay Counties, Missouri: U. S. Nat. Mus. Bull. 183, viii, 284 p.

Weyer, E. M., Jr., 1929, An Aleutian burial: Am. Mus. Nat. Hist. Anthropol. Papers, v. 31 , pt. 3, p. 219-238.

Wise, E. N., and Shutler, Dick, Jr., 1958, University of Arizona radiocarbon dates: Science, v. 127 , p. $72-74$. Wormington, H. M., 1955, A reappraisal of the Fremont Culture: Denver Mus. Nat. His-
tory Proc., no. 1,200 p.

Zumberge, J. H., and Potzger, J. E., 1955, Pollen profiles, radiocarbon dating, and geologic chronology of the Lake Michigan basin: Science, v. 121, p. 309-311. 1956, Late Wisconsin chronology of the Lake Michigan basin correlated with
pollen studies: Geol. Soc. America Bull., v. 67, p. 271-288. 